Anna Goral - Wojciech Zorawski - Otakar Bokuvka*

\title{
INFLUENCE OF THE TITANIA CONTENT ON THE MICROSTRUCTURE AND PROPERTIES OF PLASMA SPRAYED ALUMINA-TITANIA COATINGS
}

The composite alumina-titania coatings have been widely used in industry fields to protect metallic components from wear, corrosion and thereby prolonging their service time. This paper presents an analysis of the microstructure and mechanical properties of $\mathrm{Al}_{2} \mathrm{O}_{3}-\mathrm{TiO}_{2}$ composite coatings, plasma sprayed on steel substrates from feedstocks containing various concentrations of the TiO ${ }_{2}$ powder. The coatings revealed lamellar microstructure, formed by the rapid solidification of molten droplets of the powder on previously deposited splats. The main phase identified in the coatings was $\mathrm{\gamma}-\mathrm{Al}_{2} \mathrm{O}_{3}$ phase, the others were $\mathrm{TiO}_{2}$ and $\alpha-\mathrm{Al}_{2} \mathrm{O}_{3}$, as well as amorphous phase. The results indicated significant improvement of hardness, Young's modulus and fracture resistance of coatings with an increase in $\mathrm{TiO}_{2}$ from $3 \mathrm{wt}$. \% to $13 \mathrm{wt}$. \%. The friction coefficient was found to be the same for both coatings.

Keywords: $\mathrm{Al}_{2} \mathrm{O}_{3}-\mathrm{TiO}_{2}$ coating, plasma spraying, hardness, fracture resistance

\section{Introduction}

The very good combination of mechanical and thermal properties of oxide-based coatings makes them a desirable coating working in harsh conditions that involve mechanical and corrosive factors. Nowadays, the most common methods for a ceramic coating deposition are an atmospheric plasma spraying (APS) [1] and the high-velocity oxygen fuel (HVOF) thermal spraying [2]. The APS sprayed ceramic coatings are widely applied to structural materials and various machine parts in order to improve wear, oxidation and corrosion resistance [3]. The effect of spraying on fatigue properties of structural materials in the ultra-high-cycle regime was also examined; only a weak influence was observed [4]. Among the alumina-based coatings, particularly those containing $\mathrm{TiO}_{2}$ are of interest since they possess enhanced toughness and wear resistance compared to $\mathrm{Al}_{2} \mathrm{O}_{3}$ coatings [5]. They are conventionally used hard coatings for their resistance to chemical and abrasive wear characteristics. Plasma sprayed $\mathrm{Al}_{2} \mathrm{O}_{3}-\mathrm{TiO}_{2}$ coatings have been widely used as wear, corrosion and thermal resistant coatings in machinery, textile, printing, and aerospace industries [6], [7]. Addition of various amounts of $\mathrm{TiO}_{2}$ to $\mathrm{Al}_{2} \mathrm{O}_{3}$ feedstock can change their mechanical properties. Titania in alumina is intended to lower the melting temperature of the mixture due to the lower melting temperature of titania compared to the melting temperature of alumina, which in turn facilitates the melting process of alumina-titania powders [8]. In addition, the fracture toughness is an important phenomenon affecting tribological properties and this is allowed by the $\mathrm{TiO}_{2}$ additive to improve the wear resistance [9]. The wear of ceramic coatings is sensitive to their mechanical properties and therefore they should be characterized in details.
This study aims to identify the effects of $\mathrm{TiO}_{2}$ addition to $\mathrm{Al}_{2} \mathrm{O}_{3}$ powder on the mechanical behavior of plasma-sprayed $\mathrm{Al}_{2} \mathrm{O}_{3}-\mathrm{TiO}_{2}$ coatings.

\section{Experimental}

The coatings were plasma sprayed on steel substrates using the Plancer PN-120 system equipped with the Thermal Miller 1264 powder feeder. The feedstock powders were commercially available powder mixtures $\mathrm{Al}_{2} \mathrm{O}_{3}: \mathrm{TiO}_{2}$ wt. \% ratio $=87: 13$ and 97:3 (Amdry 6228, FST C-336.31, respectively). The microstructures of obtained alumina-titania coatings were characterized using the scanning electron microscope FEI E-SEM XL30 and X-ray diffraction diffractometer (D8 Discover, Bruker with $\mathrm{CoK} \alpha$ radiation). Indentation tests were performed at the $100 \mathrm{mN}$ maximum load, the $200 \mathrm{mN} / \mathrm{min}$ loading rate and unloading rate with the use of the CSEM-MCT equipment. On each coating, at least 7 indentations were made, and for further analysis, the average values were taken. The scratch tests were carried out on the MCT equipment using a Rockwell $\mathrm{C}$ diamond with a radius of $200 \mu \mathrm{m}$. The scratch distance was $5 \mathrm{~mm}$. The maximum load value $\mathrm{P}_{\max }$ was $30 \mathrm{~N}$. Changes in the load value were linear, and the range over the entire scratch distance was from $0.01 \mathrm{~N}$ to 30 $\mathrm{N}$. The rate of the indenter movement was $5 \mathrm{~mm} / \mathrm{min}$. The test and analysis were carried out in accordance with the PN-EN 1071-3 standard.

\section{Results and discussion}

The $\mathrm{Al}_{2} \mathrm{O}_{3}-3 \mathrm{TiO}_{2}$ and $\mathrm{Al}_{2} \mathrm{O}_{3}-13 \mathrm{TiO}_{2}$ coating feedstocks consisted of particles of $\alpha-\mathrm{Al}_{2} \mathrm{O}_{3}$ (rhombohedral, $\mathrm{a}=4.76 \AA$,

\footnotetext{
* ${ }^{1}$ Anna Goral, ${ }^{2}$ Wojciech Zorawski, ${ }^{3}$ Otakar Bokuvka

${ }^{1}$ Institute of Metallurgy and Materials Science PAS, Krakow, Poland

${ }^{2}$ Faculty of Mechatronics and Mechanical Engineering, Kielce University of Technology, Poland

${ }^{3}$ Faculty of Mechanical Engineering, University of Zilina, Slovakia

E-mail: a.goral@imim.pl
} 


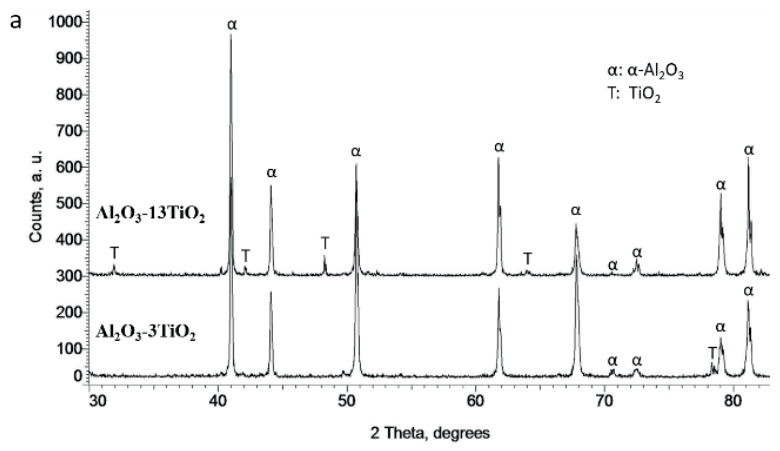

Figure $1 \mathrm{X}$-ray diffraction patterns of the $\mathrm{Al}_{2} \mathrm{O}_{3}-3 \mathrm{TiO}$, and $\mathrm{Al}_{2} \mathrm{O}_{3}-13 \mathrm{TiO}$, powders

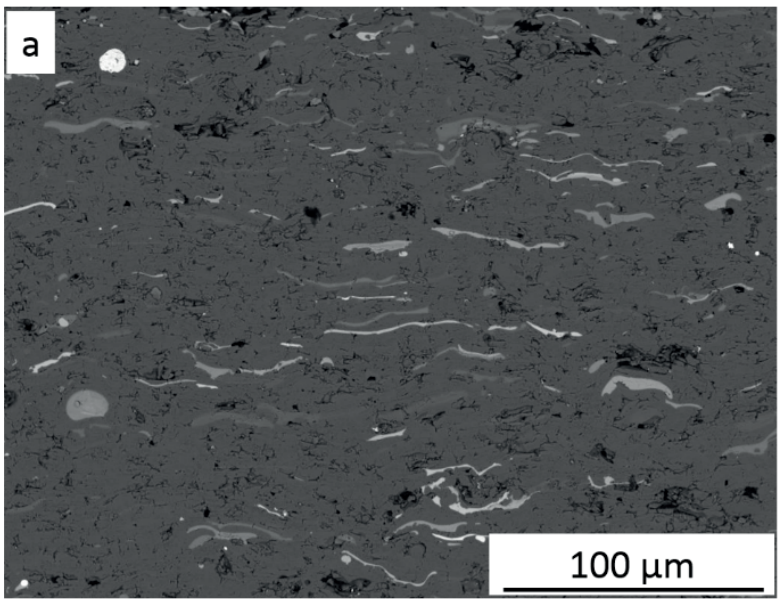

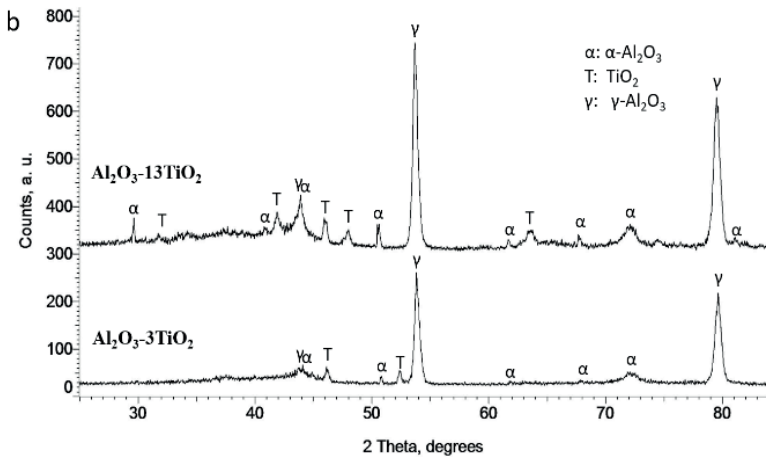

Figure 2 X-ray diffraction patterns of plasma sprayed alumina - titania coatings

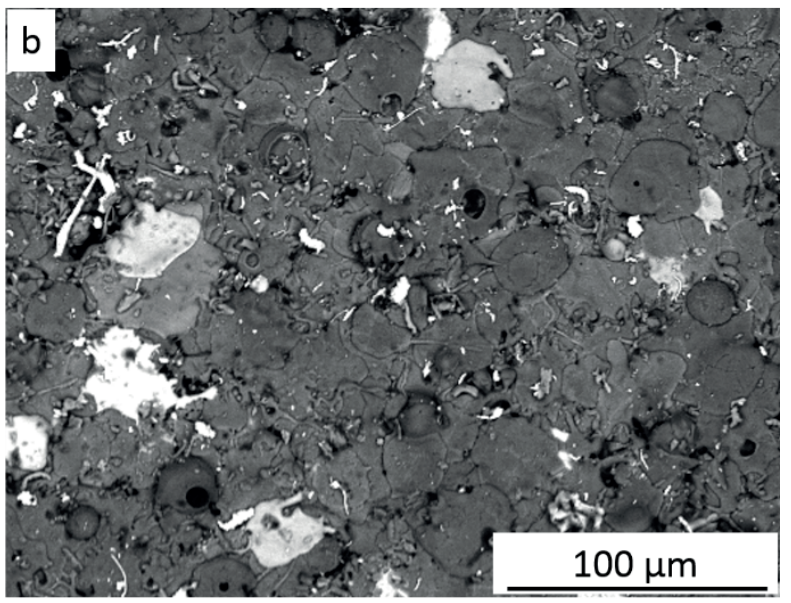

Figure 3 Microstructure of $\mathrm{Al}_{2} \mathrm{O}_{3}-3 \mathrm{TiO}$, coating a) cross section, b) surface
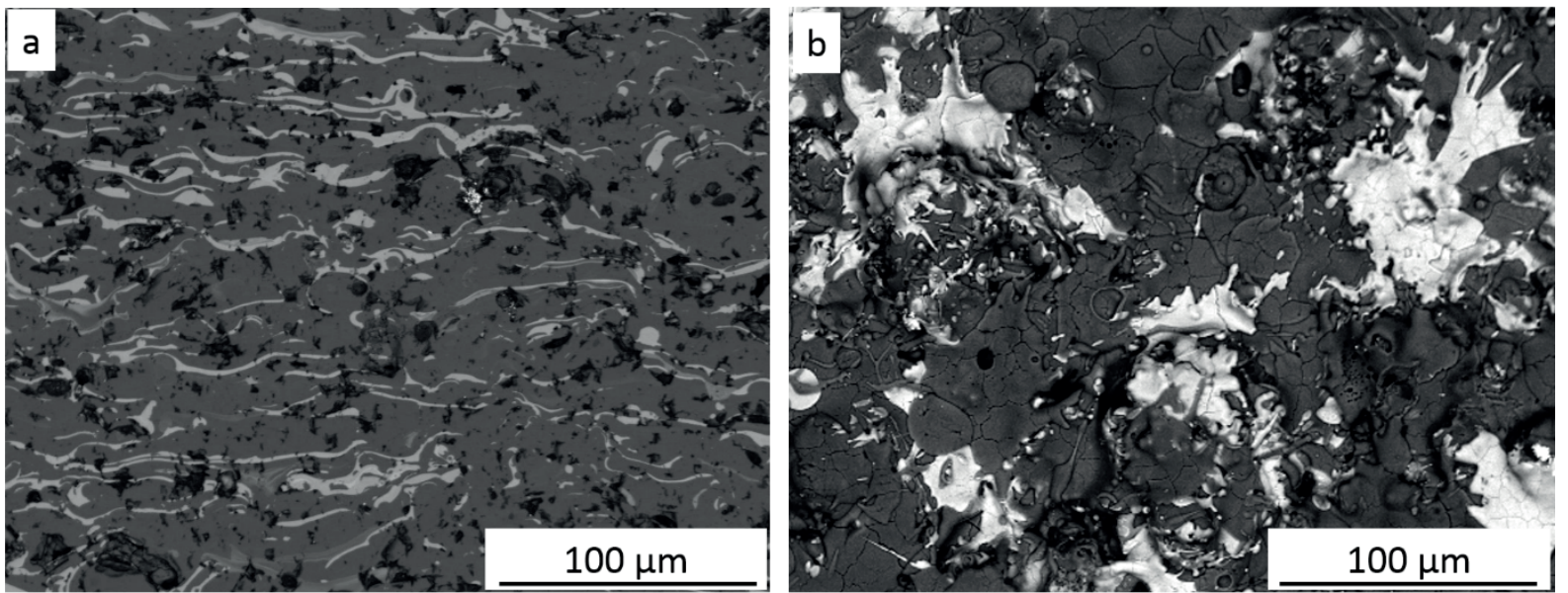

Figure 4 Microstructure of the $\mathrm{Al}_{2} \mathrm{O}_{3}-13 \mathrm{TiO}$, coating a) cross section, b) surface

$\mathrm{c}=12.99 \AA$ ) and $\mathrm{TiO}_{2}$ (tetragonal, $\mathrm{a}=4.59 \AA, \mathrm{c}=2.96 \AA$ ) phases identified using the $\mathrm{X}$-ray diffraction method, Figure 1 . The powders had irregular shapes and sizes in the range of 10-100 $\mu \mathrm{m}$. The plasma sprayed coatings revealed the above mention phases but they were constituted mainly of $\gamma-\mathrm{Al}_{2} \mathrm{O}_{3}$ (cubic, $\mathrm{a}=7.98 \AA$ ), Figure 2. The $\gamma-\mathrm{Al}_{2} \mathrm{O}_{3}$ phase is produced during the spray process from the $\alpha-\mathrm{Al}_{2} \mathrm{O}_{3}$ present in the feedstock powder due to the high flattening cooling rate (between $10^{-6}$ and $10^{-8} \mathrm{~K} / \mathrm{s}$ ). Because of a higher cooling rate $\gamma-\mathrm{Al}_{2} \mathrm{O}_{3}$ nucleates in preference to $\alpha-\mathrm{Al}_{2} \mathrm{O}_{3}$ phase [1], [10]. Additionally, the slightly raised background on the coating diffractograms in Figure 2 indicated a presence of an amorphous phase in their microstructures. That was confirmed by the TEM analysis presented in our previous paper [11].

During the plasma spraying the coatings were constituted as a result of an impaction and rapid solidification of the hightemperature and high-speed feedstock on the substrate or on the previously deposited layers. Such particles flattened and solidified rapidly at the surface of the part to be covered, forming a stacking 
Table 1 Hardness ( $\mathrm{HV}$ and $\mathrm{H}$ ) and Young's modulus measured for $\mathrm{Al}_{2} \mathrm{O}_{3}-3 \mathrm{TiO}$, and $\mathrm{Al}_{2} \mathrm{O}_{3}-13 \mathrm{TiO}_{2}$ coatings under load of $100 \mathrm{mN}$

\begin{tabular}{ccccc}
\hline Coating & $\mathrm{HV}$ & $\mathrm{H}$ & $\mathrm{E}$ & $\mathrm{H} / \mathrm{E}$ \\
{$[\mathrm{GPa}]$} & $7.2 \pm 1.0$ & $102 \pm 15$ & 0.07 \\
$\mathrm{Al}_{2} \mathrm{O}_{3}-3 \mathrm{TiO}_{2}$ & $683 \pm 99$ & $10.3 \pm 1.9$ & $124 \pm 14$ & 0.08 \\
$\mathrm{Al}_{2} \mathrm{O}_{3}-13 \mathrm{TiO}_{2}$ & $980 \pm 186$ & & \\
\hline
\end{tabular}
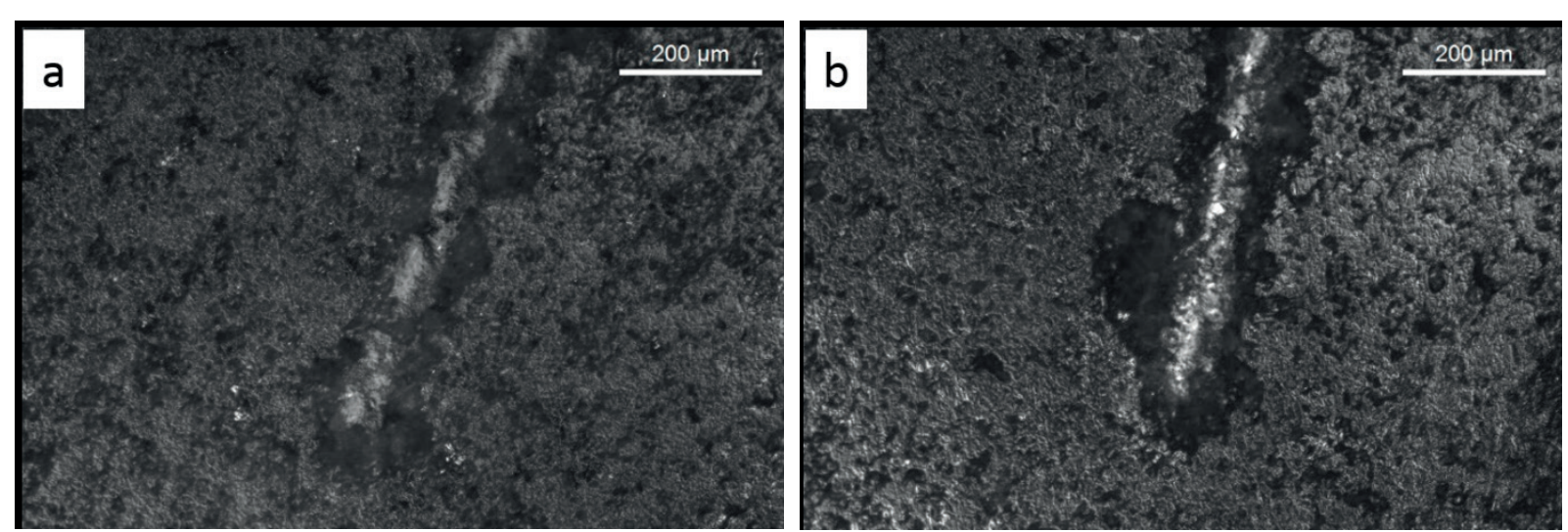

Figure 5 Microstructure of wear tracks after the scratch test of coatings a) $\mathrm{Al}_{2} \mathrm{O}_{3}-3 \mathrm{TiO}_{2}$, b) $\mathrm{Al}_{2} \mathrm{O}_{3}-13 \mathrm{TiO}_{2}$
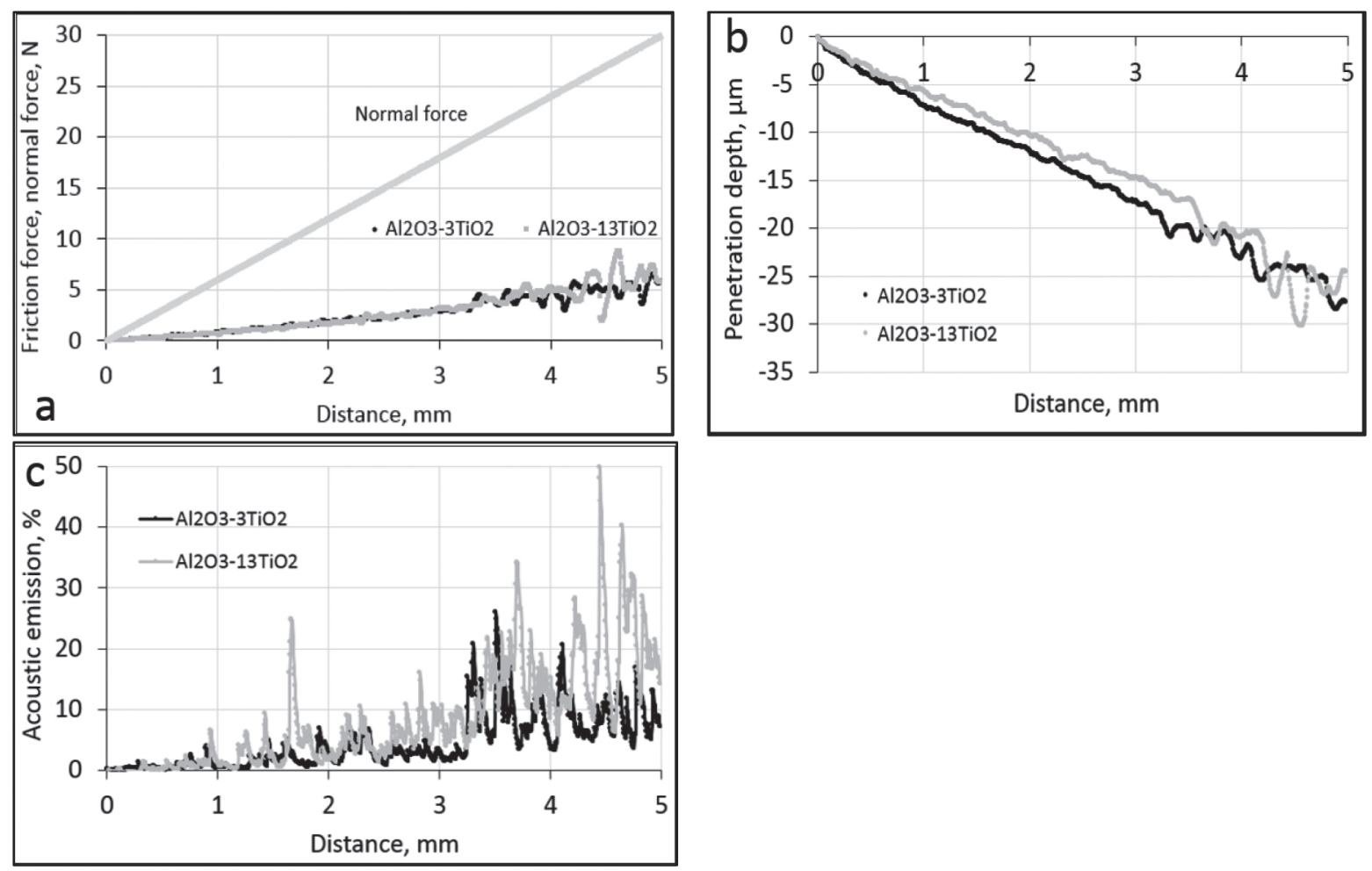

Figure 6 Properties measured for $\mathrm{Al}_{2} \mathrm{O}_{3}-3 \mathrm{TiO}_{2}$ and $\mathrm{Al}_{2} \mathrm{O}_{3}-13 \mathrm{TiO}$ coatings during the scratch tests a) friction force and normal force, b) penetration depth, c) acoustic emission

of lamellas. The layered microstructure of the $\mathrm{Al}_{2} \mathrm{O}_{3}-3 \mathrm{TiO}_{2}$ and $\mathrm{Al}_{2} \mathrm{O}_{3}-13 \mathrm{TiO}_{2}$ coatings constituted by the fully melted in the plasma flame initial powders, was composed of the $\mathrm{Al}_{2} \mathrm{O}_{3}$ matrix with areas composed of $\mathrm{TiO}_{2}$. The strips with white contrast, visible on the coating cross sections in Figure 3 and Figure 4, correspond to $\mathrm{TiO}_{2}$ phase. The phase appearing in grey contrast was mainly $\gamma-\mathrm{Al}_{2} \mathrm{O}_{3}$, although the $\alpha-\mathrm{Al}_{2} \mathrm{O}_{3}$ phase was also present as was indicated in Figure 2. The $\alpha-\mathrm{Al}_{2} \mathrm{O}_{3}$ phase was formed in the areas of coatings where the particles cooled more slowly. The detailed analysis of chemical and phase composition changes of the coatings was reported by Goral et al [11] and Zorawski et al [12]. The coatings showed a porosity content due to the voids left by the staking process and it was slightly lower for $\mathrm{Al}_{2} \mathrm{O}_{3}-3 \mathrm{TiO}_{2}$ coatings. Pores appear black in Figure 3 and Figure 4.

The indentation tests showed that the $\mathrm{Al}_{2} \mathrm{O}_{3}-13 \mathrm{TiO}_{2}$ coatings revealed for $43 \%$ higher microhardness than coatings containing less amount of $\mathrm{TiO}_{2}$ in the feedstock. Those coatings were also characterized by $21 \%$ higher Young's modulus. Moreover, the ratio between the microhardness $(\mathrm{H})$ and the elastic modulus (E) was calculated, because, according to Leyland et al. [13], the 
most durable coatings can be obtained if $\mathrm{H} / \mathrm{E}$ has a high value, i.e. sufficiently high hardness, but with a low elastic modulus. Results presented in Table 1 show that the slightly better wear resistance should be exhibited by the $\mathrm{Al}_{2} \mathrm{O}_{3}-13 \mathrm{TiO}_{2}$ coating.

To obtain the critical loads that are related to adhesion properties of coatings, the scratch tests were performed. The failure events were examined by an optical microscope. Only the cohesive cracks, resulting from over-strength of the coating, were observed as a result of the high tensile stresses behind the indenter, Figure 5.

The load at which such cracks occurred $\left(\mathrm{L}_{\mathrm{cl}}\right.$ - the first critical load) was $12 \mathrm{~N}$ and $16 \mathrm{~N}$ for $\mathrm{Al}_{2} \mathrm{O}_{3}-3 \mathrm{TiO}_{2}$ and $\mathrm{Al}_{2} \mathrm{O}_{3}-13 \mathrm{TiO}_{2}$ coatings, respectively. A fracture resistance was determined as the value of normal force when the first fracture occurs. This event was followed by a fluctuation in both force and penetration depth visible in Figure 6a-b. The corresponding acoustic emission (AE) was also measured during the test and presented in Figure 6c. An increase of the load to $23 \mathrm{~N}$ results in a significant peeling of the coating. Since no adhesion fracture was observed up to the maximum force of $30 \mathrm{~N}$, it was not possible to determine the second critical load $\left(\mathrm{L}_{\mathrm{C} 2}\right)$ parameter. This was also caused by the high thickness of the coatings. The friction coefficient determined in this test was the same for both coatings and it was equal 0.21 .

\section{Conclusions}

The plasma sprayed $\mathrm{Al}_{2} \mathrm{O}_{3}-3 \mathrm{TiO}_{2}$ and $\mathrm{Al}_{2} \mathrm{O}_{3}-13 \mathrm{TiO}_{2}$ coatings revealed layered structure with the titania strips uniformly distributed in the alumina matrix. The $\mathrm{Al}_{2} \mathrm{O}_{3}-13 \mathrm{TiO}_{2}$ coatings were characterized by enhanced mechanical properties, such as hardness, Young's modulus and fracture resistance with respect to the $\mathrm{Al}_{2} \mathrm{O}_{3}-3 \mathrm{TiO}_{2}$ coatings. The friction coefficient determined in the scratch test was the same for both coatings.

\section{References}

[1] VARGAS, F., AGEORGES, H., FOURNIER, P., FAUCHAIS, P., LOPEZ, M. E.: Mechanical and Tribological Performance of Al2O3-TiO2 Coatings Elaborated by Flame and Plasma Spraying. Surface and Coatings Technology, 205, 1132-1136, 2010. http:// dx.doi.org/10.1016/j.surfcoat.2010.07.061

[2] SINGH, H., GREWA, M. S., SEKHON, H. S., RAO, R. G.: Sliding Wear Performance of High Velocity Oxy-Fuel Spray Al2O3/ TiO2 and Cr2O3 Coatings. Journal of Engineering Tribology, 222, 601-610, 2008. https://doi.org/10.1243/13506501JET362

[3] UTU, I. D., MARGINEAN, G., HULKA, I., SERBAN, V. A., CRISTEA, D.: Properties of the Thermally Sprayed Al2O3-TiO2 Coatings Deposited on Titanium Substrate. International Journal of Refractory Metals and Hard Materials, 51, 118-123, 2015. https://doi.org/10.1016/j.jijmhm.2015.03.009

[4] NOVY, F., MINTACH, R., BOKUVKA, O.: Effect of Galvanic Metallization, PVD Processes and Thermal Spraying on Fatigue Properties of Plain Structural Steels in the Ultra-High-Cycle Regime. Communications-Scientific Letters of the University of Zilina, 12(4), 49-54, 2010.

[5] SHAW, L. L., GOBERMAN, D., REN, R., GELl, M., JIANG, G., WANG, Y., XIAO, T. D., STRUTT, P. R.: The dependency of microstructure and properties of nanostructured coatings on plasma spray conditions. Surface and Coatings Technology, 130, 1-8, 2000. https://doi.org/10.1016/S0257-8972(00)00673-3

[6] WANG, M. D., SHAW, L. L.: Effects of the Powder Manufacturing Method on Microstructure and Wear Performance of Plasma Sprayed Alumina-Titania Coatings. Surface and Coatings Technology, 202(1), 34-44, 2007. https://doi.org/10.1016/j. surfcoat.2007.04.057

[7] HABIB, K. A., SAURA, J. J., FERRER, C., DAMRA, M. S., GIMENEZ, E., CABEDO, L.: Comparison of Flame Sprayed Al2O3/TiO2 Coatings: Their Microstructure, Mechanical Properties and Tribology Behavior. Surface and Coatings Technology, 201, 1436-1443, 2006. https://doi.org/10.1016/j.surfcoat.2006.02.011

[8] GHAZALI, M. J., FORGHANI, S. M., HASSANUDDIN, N., MUCHTAR, A., DAUD, A. R.: Comparative Wear Study of Plasma Sprayed TiO2 and Al2O3-TiO2 on Mild Steels. Tribology International, 93, 681-686, 2016. https://doi.org/10.1016/j. triboint.2015.05.001

[9] KUSOGLU, I. M., CELIK, E., CETINEL, H., OZDEMIR, I., DEMIRKURT, O., ONEL, K.: Wear Behavior of Flame-Sprayed Al2O3-TiO2 Coatings on Plain Carbon Steel Substrates. Surface and Coatings Technology, 200, 1173-1177, 2005. https://doi. org/10.1016/j.surfcoat.2005.02.219

[10] WANG, D., TIAN, Z., SHEN, L., LIU, Z., HUANG, Y.: Microstructural Characteristics and Formation Mechanism of A12O3-13 wt. \% TiO2 Coatings Plasma-Sprayed with Nanostructured Agglomerated Powders. Surface and Coatings Technology, 203, 12981303, 2009. https://doi.org/10.1016/j.surfcoat.2008.10.027

[11] GORAL, A., ZORAWSKI, W., LITYNSKA-DOBRZYNSKA, L.: Study of the Microstructure of Plasma Sprayed Coatings Obtained from Al2O3-13TiO2 Nanostructured and Conventional Powders. Materials Characterization, 96, 234-240, 2014. https:// doi.org/10.1016/j.matchar.2014.08.016

[12] ZORAWSKI, W., GORAL, A., BOKUVKA, O., LITYNSKA-DOBRZYNSKA, L., BERENT, K.: Microstructure and Tribological Properties of Nanostructured and Conventional Plasma Sprayed Alumina-Titania Coatings. Surface and Coatings Technology, 268, 190-197, 2015. https://doi.org/1016/j.surfcoat.2014.09.014

[13] LEYLAND, A., MATTHEWS, A.: On the Significance of the H/E Ratio in Wear Control: A Nanocomposite Coating Approach to Optimized Tribological Behavior. Wear, 246, 1-11, 2000. https://doi.org/10.1016/S0043-1648(00)00488-9 